\title{
ODNOS SLOBODNOG VREMENA I KVALITETE ŽIVOTA SREDNJOŠKOLACA
}

\author{
Mr. sc. Marija Rattinger \\ Osnovna škola Bartola Kašića, Zagreb
}

\begin{abstract}
Sažetak:
Slobodno vrijeme, zajedno s korištenjem društvenim mrežama kao jednim od svojih imanentnih elemenata, može imati važnu ulogu u kvaliteti života srednjoškolaca. Cilj istraživanja bio je ispitati obilježja i prediktorsku ulogu slobodnog vremena i služenje društvenim mrežama u samoprocjeni kvalitete života učenika srednjih škola. Za prikupljanje podataka korišten je anketni upitnik koji osim demografskih podataka sadrži Skalu aktivnosti u slobodnom vremenu, Skalu stavova o društvenim medijima i Skalu kvalitete života. Istraživanje je provedeno na uzorku učenika srednjih škola različitih smjerova ( $N=150$ ) iz urbanih i ruralnih područja Zagreba i Zagrebačke županije. Rezultati pokazuju da su demografska obilježja ispitanika i aktivnosti u slobodnom vremenu statistički značajni prediktori samoprocjene kvalitete života ispitivanih srednjoškolaca. Stavovi o društvenim mrežama nisu se pokazali statistički značajnima. Postoji statistički značajna razlika između samoprocjene kvalitete života i učestalosti korištenja društvenim mrežama s obzirom na spol učenika.

Istraživanjem su dobivena deskriptivna obilježja određenja kvalitete života i slobodnog vremena srednjoškolaca i objašnjeni prediktorski odnosi slobodnog vremena, društvenih mreža i individualnih obilježja učenika u samoprocjeni kvalitete njihovog života.
\end{abstract}

Ključne riječi: društvene mreže, kvaliteta života, slobodno vrijeme, učenici srednjih škola.

\section{KVALITETA ŽıVOTA}

Koncept kvalitete života vrlo je istraživan koncept u različitim znanstvenim područjima, no ne postoji njegova općeprihvaćena definicija jer definicija svakog autora ovisi o njegovom istraživačkom području. Različite operacionalizacije koncepta u istraživačkom smislu rezultiraju problemima u komparabilnosti dobivenih rezultata (Kočo Vukadin, 2016).

Pokazateljima kvalitete života najčešće se smatraju: zdravstveni status, kvaliteta prehrane, kvaliteta obrazovanja, uvjeti rada (zaposlenost), kvaliteta stanovanja, odijevanja i slobodnog vremena te razina socijalne sigurnosti i ljudske slobode (Lay, 1991, prema Bouillet, 2006). Diener i Lucas (2000) ističu da kvaliteta života obuhvaća subjektivni osjećaj zadovoljstva i objektivne uvjete koji dovode do tog zadovoljstva, a koji se mogu empirijski istražiti.

Kada govorimo o kvaliteti života mlade populacije, govorimo o vrlo kompleksnom fenomenu koji možemo analizirati s različitih aspekata. On u sebi ujedinjuje različite i brojne specifičnosti koje se odnose na različita područja života. Određen je izvanjskim uvjetima (materijalnim, fizičkim, sigurnosnim, ekološkim), socijalnom organizacijom društva, pripadnošću pojedinoj društvenoj grupi i brojnim drugim okolnostima (Bouillet, 2006). Dosadašnja istraživanja slobodnog vremena i kvalitete života mladih pokazuju da je slobodno vrijeme ključno za razvoj mladog čovjeka i da mladi u sferi slobodnog vremena izgrađuju vlastite identitete (Larsen, McGraw i Cacioppo, 2001) i vlastite životne stilove (Caldwell, Baldwin, Walls i Smith, 2004), ponekad prelazeći granice konvencionalnog društva. Iz toga je dalje moguće zaključiti da je slobodno 
vrijeme važno za kvalitetu života (Iso-Ahola, 1980). Istraživanje kvalitete života trenutno obuhvaća široki spektar disciplina kao što su psihologija, sociologija, ekonomija, politika, marketing, urbanizam, medicinske znanosti, ali još uvijek ne postoji suglasnost oko njegovog preciznog pedagoškog određenja.

\section{SLOBODNO VRIJEME}

Slobodno vrijeme ne predstavlja homogenu kategoriju ponašanja i malo je dosljednosti u njegovom kategoriziranju i definiranju (Godbey, 2003; Previšić, 2000). Bez obzira na nepreciznost mnogobrojnih definicija, sve se one slažu da pod pojmom slobodnog vremena podrazumijevamo ono vrijeme koje nam preostaje nakon svih obveza, da postoje različite mogućnosti njegova provođenja i različite mogućnosti utjecaja na način njegova provođenja. One su slobodnom voljom izabrane, neobavezne su, isključuju vrijeme provedeno u školi, vrijeme provedeno u kućanskim poslovima i na radnome mjestu (Byrne, Nixon, Mayock i Whyte, 2006; Previšić, 2000).

U slobodnom se vremenu stvaraju uvjeti koji podupiru individualno iskustvo autonomije, kompetentnosti i povezanosti (Deci, Connell i Ryan 1989). Autonomija se očituje u samostalnom izboru aktivnosti prema vlastitim željama i interesima, kompetentnost u individualnoj sposobnosti i uspješnosti pri bavljenju slobodnovremenskim aktivnostima, a povezanost u odnosima s društvom s kojim se slobodno vrijeme provodi. Uvjeti u kojima se ostvaruju pozitivna iskustva i ispunjavaju psihološke potrebe pojedinca rezultiraju visokom motivacijom za aktivnošću, poboljšanom učinkovitošću, upornošću, kreativnošću i općom dobrobiti (Ryan i Deci, 2000).

Provedena istraživanja slobodnog vremena, posebno slobodnog vremena mladih (Badrić, Prskalo i Matijević, 2014; Byrne i sur., 2006; Huang, 2013; Hanžek, Holenko, Kojadin, Kolesarić i Morić, 2013; Leversen, Danielsen, Birkeland i Samdal, 2012) upućuju na to da sadržajna dimenzija provođenja slobodnog vremena mladih određuje njihov prepoznatljiv životni stil. Istraživanja dokazuju (Ilišin, 2000) da je aktivno smisleno provođenje slobodnog vremena povezano s razvojem ličnosti.

\section{DRUŠTVENE MREŽE}

Mladi su više nego ostale dobne skupine osjetljivi na modne trendove (Roberts i sur., 1999), pa su tako online društveni mediji i internet vrlo brzo usvojeni i integrirani u sve segmente njihovog života, a tako i u velik dio njihovog slobodnog vremena. Oni imaju tendenciju ranijeg usvajanja digitalnih komunikacijskih sposobnosti i njihova izloženost digitalnim medijima neprestano raste u volumenu, složenosti i interaktivnosti (Roberts, Foehr i Rideout, 2005; Roberts i sur., 1999). Rođeni su u svijetu digitalnih tehnologija i ne poznaju svijet bez velikog broja televizijskih programa, internet im je glavni izvor informacija i zabave te je upotreba mobilnih tehnologija imanentni element njihovih svakodnevnih aktivnosti (Car, 2010). Društvene mreže (online) mladima daju novi, veći prostor za druženje i povezivanje (Car, 2013), ali i mijenjaju način komunikacije unutar svih socijalizacijskih faktora kao i cjelokupnu kulturu provođenja slobodnog vremena (Tapscott, 2009). Time su društveni mediji dobili ključnu ulogu u životima umrežene mladeži. Posredstvom mreže mladi često dopunjuju svoje susrete licem u lice (Boyd, 2014; Car, 2010), a suvremena tehnologija pruža neograničene mogućnosti umrežavanja i komuniciranja. Zbog brzog prihvaćanja suvremenih medija i služenja njima, a posebno društvenim mrežama, u opisu novih generacija mladih pojavljuju se i novi pojmovi poput "netgeneracije“, „milenijske generacije“ (Howe i Strauss, 2000) i „digitalni urođenici“ (Prensky, 2005). 
Kako se kvaliteta života mladih izravno povezuje s načinom provođenja njihovog slobodnog vremena (Perasović i Bartoluci, 2008; Wang i Kao, 2006), a internet i društvene mreže postali su vodeća aktivnost u slobodnom vremenu adolescenata, nametnula se potreba istraživanja odnosa između aktivnosti u slobodnom vremenu, stavova o društvenim mrežama i kvalitete njihovog života.

\section{CIU I ZADATCI ISTRAŽIVANJA}

Cilj je ovog istraživanja bio ispitati i objasniti obilježja i prediktorsku ulogu slobodnog vremena i društvenih mreža u samoprocjeni kvalitete života srednjoškolaca.

Zadatci istraživanja bili su ispitati kakav je odnos između demografskih obilježja srednjoškolaca, aktivnosti kojima se bave u slobodno vrijeme i samoprocjene kvalitete njihovog života, ispitati postoje li razlike u samoprocjeni kvalitete života s obzirom na spol, mjesto življenja i vrstu škole koju pohađaju te postoji li razlika u učestalosti korištenja društvenim mrežam s obzirom na spol učenika.

Krenulo se od pretpostavke da su demografska obilježja ispitanika i aktivnosti u slobodnom vremenu statistički značajni prediktori kvalitete života učenika, da ne postoji statistički značajna razlika u samoprocjeni kvalitete života s obzirom na spol, mjesto življenja i vrstu škole koju pohađaju te da ne postoji razlika u učestalosti korištenja društvenih mreža s obzirom na spol učenika.

\section{UZORAK}

Uzorak čine učenici od 1 . do 4. razreda srednje škole, različitih smjerova, iz urbanih i ruralnih područja Zagreba i Zagrebačke županije.

Od ukupnog broja ispitanika ( $N=150) 58$ je muškog (39\%) i 92 ženskog spola (61\%). Dob ispitanika je od 14 do 19 godina, najviše je anketirano petnaestgodišnjaka i sedamnaestgodišnjaka. Prosječna je dob anketiranih učenika 16,3 $\pm 1,14$ godina, dok je medijan 16 . Od ukupnog broja u gradu živi 85 ispitanika (57\%), dok njih 65 (43\%) živi u selu. Najviše ispitanih učenika pohađa gimnaziju (25\%), slijede polaznici škole za modu i dizajn (23\%), ostali smjerovi jesu hotelijersko-turistički tehničar (14\%), prodavač (14\%), kuhar, konobar, slastičar (11\%), ekonomska škola $(10 \%)$ te polaznici centra za obrazovanje (2\%). Prema općem uspjehu u prethodnom razredu $u$ istraživanju je sudjelovao 1 ispitanik s negativnim općim uspjehom u prethodnom razredu, 3 ispitanika s dovoljnim, 42 učenika s dobrim, 66 učenika s vrlo dobrim i 38 učenika s odličnim uspjehom. Kao što je vidljivo, najčešća ocjena učenika bila je vrlo dobar (kod $44 \%$ učenika) koliko iznosi i medijan.

\section{INSTRUMENTI I POSTUPAK PRIKUPLANJA PODATAKA}

Za potrebe ovog istraživanja formiran je anketni upitnik koji se sastojao od sociodemografskih pitanja koja su se odnosila na dob, spol, mjesto življenja, vrstu škole, školski uspjeh u prethodnom razredu. Ispitana je prosječna količina slobodnog vremena dnevno, korištenje društvenim mrežama, vrste društvenih mreža kojima se koriste, broj sati dnevno provedenih na društvenim mrežama i u koje svrhe. Upitnik čine i tri preuzeta i povratno prevedena instrumenta uz dopuštenje njihovih autora: Skala aktivnosti u slobodnom vremenu (Deci i Ryan, 1989) koja se sastoji od dvadeset jedne tvrdnje Likertove skale od pet stupnjeva (od 1= uopće se ne slažem do 5= u potpunosti se slažem), Skala stavova o društvenim mrežama koja je modificirana Skala stavova o Internetu (Tsai, Lin i Tsai, 2001) koja se sastoji se od ukupno osamnaest mani- 
festnih tvrdnji Likertove skale od pet stupnjeva ( $1=\mathrm{u}$ potpunosti se ne odnosi na mene do $5=$ u potpunosti se odnosi na mene) i Skala kvalitete života (Wang i Kao, 2006) koju čini devetnaest tvrdnji Likertove skale od pet stupnjeva od ( $1=$ uopće se ne slažem do $5=u$ potpunosti se slažem).

Anketni upitnici ispunjavani su u školama u neposrednom kontaktu ispitivačice i ispitanika.

Prikupljeni podatci uneseni su u SPSS datoteku i na osnovi te datoteke izvedene su statističke analize. Korištena je deskriptivna statistika (postotci, srednje vrijednosti, mjere disperzije) te inferencijalne metode statističke analize (hi-kvadrat test, t-test i F-test razlike između aritmetičkih sredina).

\section{REZULTATI I RASPRAVA}

Anketirani učenici najčešće imaju po pet sati slobodnog vremena dnevno, a prosjek sati iznosi 4,55 $\pm 2,59$ dok je medijan 4. Taj je podatak u skladu s podatcima o broju sati slobodnog vremena dnevno u prethodnim istraživanjima (Hanžek, Holenko, Kojadin, Kolesarić i Morić, 2013; Ilišin, Marinović-Bobinac i Radin, 2001). Učenici su dosta heterogeni s obzirom na broj sati slobodnog dnevnog vremena. Broj sati varira od nula do nerealnih 12 sati te je koeficijent varijacije povišen, iznosi $57 \%$. Distribucija učenika s obzirom na broj sati slobodnog vremena nije slična normalnoj distribuciji kako to pokazuju rezultati Kolmogorov-Smirnovljevog testa $(z=1,846 p=0,002)$.

Na pitanje koriste li se društvenim mrežama potvrdno je odgovorilo 144 učenika (96\%), četiri učenika ih ne koristi, dok dva učenika nisu dala odgovor, stoga je u nekim rezultatima iskazana suma frekvencija od 144, a ne 150.

Tablica 1. Društvene mreže kojima se učenici koriste $(N=150)$

\begin{tabular}{|l|c|c|}
\hline Vrsta društvene mreže & br. uč. & \% uč. \\
\hline Instagram & 128 & 85 \\
\hline Facebook & 80 & 53 \\
\hline Snapchat & 70 & 47 \\
\hline Twitter & 22 & 15 \\
\hline WhatsApp & 17 & 11 \\
\hline Viber & 11 & 7 \\
\hline Messenger & 8 & 5 \\
\hline Discord & 7 & 5 \\
\hline YouTube & 7 & 5 \\
\hline Reddit & 3 & 2 \\
\hline ostale mreže & 2 & 1 \\
\hline
\end{tabular}

Učenici se u najvećem postotku koriste društvenom mrežom Instagram. lako je Facebook vodeća mreža prema broju korisnika u Hrvatskoj, broj korisnika Instagrama u velikom je porastu (Arbona, 2018). To se svakako primjećuje i kod populacije učenika srednjih škola.

Pokazalo se da najveći broj ispitanika koristi dvije ili tri društvene mreže. Medijan je dva i prosjek od 2,4 $\pm 0,98$, a dnevno koristeći se društvenim mrežama provode u prosjeku 2,3 sata. Najveći se broj ispitanika izjasnio da se koriste mrežama tri i više sati dnevno (41\%), zatim dva sata (30\%), jedan sat (18\%), manje od jednog sata ( $8 \%$ ) i tri učenika ili se njima uopće ne koriste.

Pokazala se statistički značajna povezanost između spola i vremena dnevnog korištenja društvenim mrežama $\left(\chi^{2}=16,166 ; N=147 ; d f=3 ; p=0,001\right)$. Učenice se više koriste društvenim 
mrežama od učenika. Prosjek za ispitanike muškog spola iznosi približno 1,9 sati dnevno, a za ispitanike ženskog spola približno 2,5 sata dnevno. Te su aritmetičke sredine statistički značajno različite $(t=3,547 ; p=0,001)$ (Tablica 2 ).

Tablica 2. Ispitanici prema spolu i broju sati dnevnog korištenja društvenim mrežama $(\mathrm{N}=147)$

\begin{tabular}{|c|c|c|c|c|c|}
\hline $\begin{array}{c}\text { Vrijeme korištenja } \\
\text { društvenim mrežama }\end{array}$ & muški & ženski & ukupno & \% muški & \% ženski \\
\hline manje od 1 sata tj. & 8 & 5 & 13 & 14 & 6 \\
\hline 1 sat dnevno & 18 & 9 & 27 & 31 & 10 \\
\hline 2 sata dnevno & 14 & 31 & 45 & 25 & 34 \\
\hline 3 i više sati dnevo & 17 & 45 & 62 & 30 & 50 \\
\hline Ukupno & 57 & 90 & 147 & 100 & 100 \\
\hline
\end{tabular}

Kao najčešću svrhu korištenja društvenim mrežama navode kontakte s prijateljima putem pričaonice (chat) ili poruka (40,5\% slučajeva) te pregledavanje fotografija i videozapisa ( $27,5 \%$ slučajeva) što čini $2 / 3$ od svih navedenih načina korištenja. Ovi su podatci u skladu s podatcima istraživanja koje su proveli Ilišin, Bouillet, Gvozdanović i Potočnik (2013). Navedeno potvrđuje činjenicu da se mladi koriste društvenim mrežama kako bi produžili susrete sa svojim prijateljima i što više bili u kontaktu (Boyd, 2014).

Rezultati deskriptivne statističke analize podataka o aktivnostima u slobodnom vremenu (Tablica 3) pokazuju ekstremno niske $(1,65)$ kao i ekstremno visoke $(4,61)$ vrijednosti aritmetičkih sredina.

Tablica 3. Rezultati deskriptivne statističke analize podataka o aktivnostima u slobodnom vremenu $(\mathrm{N}=150)$

\begin{tabular}{|c|c|c|c|c|c|}
\hline $\begin{array}{l}\text { Red. } \\
\text { br. }\end{array}$ & Tvrdnja & 흔 $\frac{\frac{\pi}{\frac{\pi}{c}}}{\frac{1}{0}}$ & 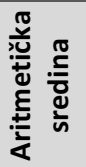 & 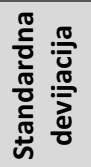 & 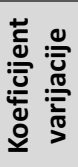 \\
\hline 1. & $\begin{array}{l}\text { Sam/sama odabirem aktivnosti koje želim raditi u slobodno } \\
\text { vrijeme. }\end{array}$ & 150 & 4,52 & 0,757 & 17 \\
\hline 2. & Volim ljude s kojima provodim slobodno vrijeme. & 150 & 4,61 & 0,665 & 14 \\
\hline 3. & $\begin{array}{l}\text { Mislim da nisam jako dobar/dobra u onome što radim u } \\
\text { slobodno vrijeme. } \mathrm{N}\end{array}$ & 150 & 2,51 & 1,284 & 51 \\
\hline 4. & $\begin{array}{l}\text { Osjećam stres dok se bavim aktivnostima u slobodnom } \\
\text { vremenu. } \mathrm{N}\end{array}$ & 150 & 1,71 & 1,046 & 61 \\
\hline 5. & $\begin{array}{l}\text { Osobe koje poznajem kažu da sam dobar/dobra u onome što } \\
\text { radim u slobodno vrijeme. }\end{array}$ & 150 & 3,70 & 0,995 & 27 \\
\hline 6. & $\begin{array}{l}\text { Slažem se s ljudima koje susrećem na aktivnostima u slobodno } \\
\text { vrijeme. }\end{array}$ & 150 & 4,09 & 1,016 & 25 \\
\hline 7. & Uglavnom sam/sama provodim slobodno vrijeme. & 150 & 2,61 & 1,219 & 47 \\
\hline 8. & $\begin{array}{l}\text { Osjećam se slobodnim/slobodnom izraziti svoje ideje i mišljenja } \\
\text { za vrijeme aktivnosti u slobodnom vremenu. }\end{array}$ & 150 & 4,18 & 0,935 & 22 \\
\hline 9. & Ljude s kojima provodim slobodno vrijeme smatram prijateljima. & 150 & 4,45 & 0,864 & 19 \\
\hline 10. & $\begin{array}{l}\text { Aktivnostima kojima se bavim u slobodnom vremenu naučim } \\
\text { nove i zanimljive stvari. }\end{array}$ & 150 & 3,76 & 1,060 & 28 \\
\hline 11. & U svoje slobodno vrijeme moram raditi ono što mi drugi kažu. N & 150 & 1,78 & 1,022 & 57 \\
\hline
\end{tabular}




\begin{tabular}{|l|l|c|c|c|c|}
\hline 12. & Ljudi s kojima provodim slobodno vrijeme brinu o meni. & 150 & 3,85 & 1,032 & 27 \\
\hline 13. & $\begin{array}{l}\text { Mislim da sam dobar/dobra u onome čime se bavim u slobodno } \\
\text { vrijeme. }\end{array}$ & 150 & 4,08 & 0,901 & 22 \\
\hline 14. & $\begin{array}{l}\text { Osobe s kojima obično provodim slobodno vrijeme brinu o tome } \\
\text { kako se osjećam. }\end{array}$ & 150 & 3,77 & 1,100 & 29 \\
\hline 15. & $\begin{array}{l}\text { Nemam puno prilike pokazati koliko sam dobar u onome čime se } \\
\text { bavim u slobodno vrijeme. }\end{array}$ & 150 & 2,97 & 1,144 & 39 \\
\hline 16. & $\begin{array}{l}\text { Među ljudima s kojima provodim slobodno vrijeme nema } \\
\text { mnogo onih koje smatram dobrim prijateljima. N }\end{array}$ & 150 & 2,21 & 1,200 & 54 \\
\hline 17. & U slobodno vrijeme osjećam se usamljeno. N & 150 & 1,87 & 1,085 & 58 \\
\hline 18. & Ne sviđaju mi se ljudi s kojima provodim slobodno vrijeme. N & 150 & 1,65 & 0,983 & 60 \\
\hline 19. & Često se ne osjećam dobro u aktivnostima u slobodno vrijeme. N & 150 & 1,99 & 1,240 & 62 \\
\hline 20. & Nemam često priliku reći što želim raditi u slobodno vrijeme. N & 150 & 2,13 & 1,213 & 57 \\
\hline 21. & $\begin{array}{l}\text { Ljudi s kojima provodim slobodno vrijeme uglavnom se } \\
\text { prijateljski odnose prema meni. }\end{array}$ & 150 & 4,19 & 0,986 & 24 \\
\hline
\end{tabular}

Kao što vidimo, najniže ocijenjene tvrdnje negativno su formulirane, stoga su njihove modalne vrijednosti 1 (označene sa $\mathrm{N}$ ) i idu u prilog najviše ocijenjenim tvrdnjama. Iz ovih podataka vidimo da srednjoškolci imaju autonomiju u odabiru aktivnosti u slobodnom vremenu, da provode vrijeme s osobama koje smatraju prijateljima i koje vole, da se u slobodno vrijeme osjećaju dobro i ugodno, bez stresa. Oni smatraju da su dobri i uspješni u aktivnostima kojima se bave u slobodno vrijeme, da imaju priliku izraziti svoje mišljenje i da ih okolina uvažava, te se uočava njihovo međusobno prijateljstvo i povezanost.

Tablica 4. Rezultati deskriptivne statističke analize podataka o stavovima o društvenim mrežama $(\mathrm{N}=150)$

\begin{tabular}{|c|c|c|c|c|c|}
\hline $\begin{array}{l}\text { Red. } \\
\text { Br. }\end{array}$ & Tvrdnja & ס & 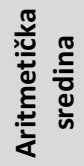 & 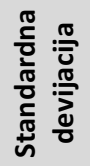 & 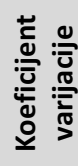 \\
\hline 1. & $\begin{array}{l}\text { Društvene mreže ono što radim čine interesantnijim i } \\
\text { maštovitijim. }\end{array}$ & 150 & 3,63 & 1,115 & 31 \\
\hline 2. & Društvene mreže šire moje obzore. & 150 & 3,54 & 1,202 & 34 \\
\hline 3. & Društvene mreže čine veliki doprinos ljudskom životu. & 150 & 3,21 & 1,255 & 39 \\
\hline 4. & $\begin{array}{l}\text { Društvene mreže pomažu mi da dobijem potrebne i važne } \\
\text { informacije. }\end{array}$ & 150 & 3,90 & 1,022 & 26 \\
\hline 5. & Društvene mreže čine društvo naprednijim. & 150 & 3,15 & 1,292 & 41 \\
\hline 6. & $\begin{array}{l}\text { Ustručavam se koristiti društvenim mrežama da se ne } \\
\text { osramotim. }\end{array}$ & 150 & 1,94 & 1,211 & 62 \\
\hline 7. & $\begin{array}{l}\text { Ako imam priliku koristiti se društvenim mrežama, bojim se da } \\
\text { ne napravim neku štetu. }\end{array}$ & 150 & 1,99 & 1,204 & 61 \\
\hline 8. & Društvene mreže mi izazivaju nelagodu. & 150 & 1,67 & 0,980 & 59 \\
\hline 9. & Korištenje društvenih mreža mi je dosadno. & 150 & 1,91 & 1,223 & 64 \\
\hline 10. & $\begin{array}{l}\text { Nisam baš sigurna/siguran u ono što radim putem društvenih } \\
\text { mreža. }\end{array}$ & 150 & 1,83 & 1,032 & 56 \\
\hline 11. & $\begin{array}{l}\text { Vjerojatno mogu naučiti većinu stvari koje trebam znati o } \\
\text { društvenim mrežama. }\end{array}$ & 150 & 3,23 & 1,238 & 38 \\
\hline 12. & $\begin{array}{l}\text { Trebam iskusnu osobu u blizini kada se koristim društvenim } \\
\text { mrežama. }\end{array}$ & 150 & 1,51 & 1,008 & 67 \\
\hline
\end{tabular}


Marija Rattinger ODNOS SLOBODNOG VREMENA I KVALITETE ŽIVOTA...

\begin{tabular}{|l|l|r|r|r|r|}
\hline 13. & $\begin{array}{l}\text { Kada naiđem na problem koristeći se društvenim mrežama, } \\
\text { obično to mogu nekako riješiti. }\end{array}$ & 150 & 3,70 & 1,174 & 32 \\
\hline 14. & $\begin{array}{l}\text { Ne trebam nikoga da mi govori o najboljim načinima korištenja } \\
\text { društvenim mrežama. }\end{array}$ & 150 & 3,57 & 1,472 & 41 \\
\hline 15. & $\begin{array}{l}\text { Mogu se koristiti društvenim mrežama samostalno, bez ičije } \\
\text { pomoći. }\end{array}$ & 150 & 4,47 & 0,960 & 21 \\
\hline 16. & $\begin{array}{l}\text { Koristim se društvenim mrežama u školi samo kada se to od } \\
\text { mene traži. }\end{array}$ & 150 & 2,77 & 1,467 & 53 \\
\hline 17. & Redovito se koristim društvenim mrežama u školi. & 150 & 3,17 & 1,435 & 45 \\
\hline 18. & Provodim puno vremena koristeći se društvenim mrežama. & 150 & 3,52 & 1,289 & 37 \\
\hline
\end{tabular}

Deskriptivni pokazatelji podataka o stavovima o društvenim mrežama $(\mathrm{N}=150)$ pokazuju da mladi smatraju društvene mreže korisnima, smatraju ih važnim sredstvom informiranja, čine njihov život interesantnijim i maštovitijim i društvo čine naprednijim. Većina se smatra kompetentnima za samostalno korišenje društvenim mrežama, one im one ne izazivaju nelagodu, sigurni su u ono što rade putem društvenih mreža, nisu im dosadne i nemaju nikakvih bojazni služeći se njima. Svojim su odgovorima pokazali da i sami uočavaju da dosta vremena provode koristeći se društvenim mrežama.

Što se tiče disperzije odgovora ispitanika ona je osrednja ili povećana (koeficijenti varijacije kreću se između $26 \%$ i $67 \%$ ). Ispitanici su s obzirom na svoje stavove o društvenim mrežama relativno homogeni ili umjereno heterogeni.

Tablica 5. Rezultati deskriptivne statističke analize podataka o samoprocjeni kvalitete života $(\mathrm{N}=150)$

\begin{tabular}{|c|c|c|c|c|c|}
\hline $\begin{array}{l}\text { Red. } \\
\text { br. }\end{array}$ & Tvrdnja & 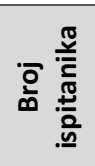 & 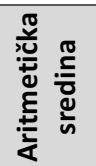 & 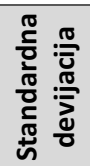 & 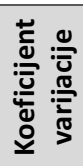 \\
\hline 1. & Uživam u životu. & 150 & 4,05 & 1,067 & 26 \\
\hline 2. & Moj život ima smisao. & 150 & 3,95 & 1,183 & 30 \\
\hline 3. & Imam sposobnost koncentracije. & 150 & 3,71 & 1,096 & 30 \\
\hline 4. & Osjećam se sigurno u svakodnevnom životu. & 150 & 4,05 & 1,077 & 27 \\
\hline 5. & Živim u zdravom okruženju. & 150 & 3,99 & 1,046 & 26 \\
\hline 6. & Imam dovoljno energije za život. & 150 & 3,97 & 1,144 & 29 \\
\hline 7. & Zadovoljan/zadovoljna sam svojim spavanjem. & 150 & 3,37 & 1,495 & 44 \\
\hline 8. & Mogu prihvatiti svoj vanjski izgled. & 150 & 3,90 & 1,268 & 33 \\
\hline 9. & Imam dovoljno novca. & 150 & 4,03 & 0,937 & 23 \\
\hline 10. & Lako dobivam dnevne informacije. & 150 & 4,11 & 1,004 & 24 \\
\hline 11. & Imam slobodnog vremena. & 150 & 4,07 & 1,103 & 27 \\
\hline 12. & Zadovoljan/zadovoljna sam podrškom svojih prijatelja. & 150 & 4,17 & 1,054 & 25 \\
\hline 13. & $\begin{array}{l}\text { Zadovoljan/zadovoljna sam svojom sposobnošću } \\
\text { obavljanja rutinskih dnevnih aktivnosti. }\end{array}$ & 150 & 3,95 & 1,009 & 26 \\
\hline 14. & Zadovoljan/zadovoljna sam svojim radnim sposobnostima. & 150 & 4,00 & 1,023 & 26 \\
\hline 15. & Zadovoljan/zadovoljna sam sobom. & 150 & 4,08 & 0,980 & 24 \\
\hline 16. & Zadovoljan/zadovoljna sam svojim međuljudskim odnosima & 150 & 4,08 & 1,046 & 26 \\
\hline 17. & Zadovoljan/zadovoljna sam svojim životnim uvjetima. & 150 & 4,39 & 0,919 & 21 \\
\hline 18. & Zadovoljan/zadovoljna sam brigom za moje zdravlje. & 150 & 4,26 & 0,951 & 22 \\
\hline 19. & Zadovoljan/zadovoljna sam svojom mobilnošću. & 150 & 4,08 & 1,065 & 26 \\
\hline
\end{tabular}


Čak sedamnaest tvrdnji o kvaliteti života (Tablica 5) srednjoškolci su pretežno prihvatili s najvećim stupnjem prihvaćanja ( $5=$ u potpunosti se slažem). Iznimka su samo dvije tvrdnje, tvrdnja 3 i tvrdnja 13, kod kojih je najveća apsolutna frekvencija za jedan stupanj niža (4 = uglavnom se slažem).

Možemo zaključiti da su uglavnom zadovoljni kvalitetom života. To potvrđuju prethodna istraživanja (Ilišin, Bouillet, Gvozdanović i Potočnik, 2013; Ilišin i Spajić Vrkaš, 2015) čiji podatci također pokazuju da su mladi zadovoljni svojim životom. Najniže su aritmetičke sredine, iako su i one dosta visoke, kod dviju tvrdnji: Zadovoljan/zadovoljna sam svojim spavanjem i Imam sposobnost koncentracije. Najveće su zadovoljstvo iskazali kod dviju tvrdnji: Zadovoljan/zadovoljna sam brigom za moje zdravlje i Zadovoljan/zadovoljna sam svojim životnim uvjetima.

Možemo zaključiti da su ispitani učenici zadovoljni sobom, svojom radnom sposobnošću i međuljudskim odnosima. Smatraju da njihov život ima smisao, uživaju u životu, uglavnom imaju dobru mogućnost koncentracije i dovoljno životne energije. Dobro prihvaćaju svoj vanjski izgled. Smatraju se informiranima i imaju vremena za sebe i aktivnosti po vlastitim željama. Zadovoljni su životnim uvjetima, mobilnošću i zdravstvenom skrbi.

Nešto niže ocijenjena tvrdnja o zadovoljstvu spavanjem u skladu je s njihovom dobi. Ne začuđuje niža procjena zadovoljstva spavanjem jer adolescenti progresivno kasnije odlaze na spavanje te zbog škole i drugih obaveza nemaju dovoljno sna, a optimalna alertnost u adolescenciji zahtijeva u prosjeku devet sati sna svake noći (Carskadon i Acebo, 2002; prema Escribano, Diaz-Morales, Delgado i Collado, 2012). Posljedica nedovoljnog sna je umor koji može biti povezan s uočavanjem nedovoljne koncentracije, a jedan je od problema u adolescenciji depresija koja se manifestira na različite načine, a jedan od pokazatelja je i gubitak koncentracije (Žitnik i Maglica, 2002) što, kako vidimo, adolescenti i sami uviđaju. Po samoprocjeni kvalitete života dosta su homogeni (koeficijenti varijacije kreću se između $21 \%$ i $44 \%$ ).

Za potrebe analize pouzdanosti deset je tvrdnji iz skale o aktivnostima u slobodnom vremenu rekodirano budući da su te tvrdnje izrečene u negativnom obliku (tvrdnje 3, 4, 7, 11, $15,16,17,18,19$ i 20). Nakon toga izvedena je analiza pouzdanosti (Reliability Analysis) triju skala sa 21,18 odnosno 19 čestica (items).

Tablica 6. Rezultati analize pouzdanosti po skupinama varijabli

\begin{tabular}{|c|c|c|c|c|c|c|c|}
\hline $\begin{array}{l}\text { Red. } \\
\text { br. }\end{array}$ & Skupina varijabli & $\begin{array}{l}\text { Pripadajuće } \\
\text { varijable }\end{array}$ & $\mathbf{N}$ & $\begin{array}{c}\text { Koefic. } \\
\text { pouzd. } \\
\alpha^{1}\end{array}$ & $\begin{array}{l}\text { Poželjno } \\
\text { brisanje } \\
\text { varijabli }^{2}\end{array}$ & $\begin{array}{c}\text { Najmanji } \\
\text { koef. } \\
\text { korelacije } \\
\text { među } \\
\text { varijablama }\end{array}$ & $\begin{array}{l}\text { Pouzda- } \\
\text { nost }\end{array}$ \\
\hline 1. & $\begin{array}{l}\text { Skala aktivnosti u } \\
\text { slobodnom } \\
\text { vremenu }\end{array}$ & sv1 do sv21 & 150 & 0,815 & sv7 i sv15 & $\begin{array}{c}\text { nema ispod } \\
0,181\end{array}$ & dobra \\
\hline 2. & $\begin{array}{c}\text { Skala stavova o } \\
\text { društvenim } \\
\text { mrežama }\end{array}$ & $\begin{array}{l}\mathrm{dm} 1 \text { do } \\
\mathrm{dm} 18\end{array}$ & 150 & 0,643 & $\begin{array}{c}\text { dm7 do dm10 } \\
\text { te } \\
\text { dm13 do dm16 }\end{array}$ & $-0,066$ & zadovolj. \\
\hline 3. & $\begin{array}{c}\text { Skala kvalitete } \\
\text { života }\end{array}$ & kv1 do kv19 & 150 & 0,928 & nema & $\begin{array}{c}\text { nema ispod } \\
0,394\end{array}$ & visoka \\
\hline
\end{tabular}

1 Cronbach alpha manji od 0,6 smatra se nezadovoljavajućom pouzdanosti, veći od 0,7 znači zadovoljavajuću pouzdanost, veći od 0,8 znači dobru pouzdanost, a veći od 0,9 znači visoku pouzdanost (Turjačanin, 2006, 137)

2 Ako bi brisanje neke od varijabli povećalo pouzdanost, tada je ovdje navedena varijabla koju bi trebalo brisati.

3 Ako se $u$ analizi pouzdanosti dobiva koeficijent korelacije manji od 0,15 , tada se radi o varijabli sa lošom diskriminativnosti koja snižava pouzdanost. 
Ta je analiza napravljena alfa modelom po pojedinim skupinama varijabli (Tablica 6). Prihvaćanje pojedinih tvrdnji međusobno je dobro usklađeno po skalama. Isključivanje pojedinih varijabli vrlo bi malo povećalo pouzdanost pa to isključivanje nije učinjeno.

Provjera normalnosti raspodjele triju numeričkih varijabli (skala) provedena je pomoću Kolmogorov-Smirnovljevog testa (Tablica 7). Ustanovljeno je da su sve tri distribucije slične normalnoj $(p>0,05)$ što znači da je kod primjene inferencijalne statističke analize moguće koristiti parametrijske testove.

Tablica 7. Rezultati provjere normalnosti raspodjele kod triju omjernih varijabli $(N=150)$

\begin{tabular}{|l|l|c|r|r|c|}
\hline $\begin{array}{c}\text { Red. } \\
\text { br. }\end{array}$ & $\begin{array}{c}\text { Varijable za koje je provedeno testiranje } \\
\text { normalnosti raspodjele pomoću KS testa }\end{array}$ & $\mathbf{N}$ & $\mathbf{Z}$ & $\mathbf{p}$ & $\begin{array}{c}\text { Distribucija je } \\
\text { približno } \\
\text { normalna }\end{array}$ \\
\hline 1. & Aktivnosti u slobodno vrijeme (skala1) & 150 & 0,874 & 0,429 & $\mathrm{da}$ \\
\hline 2. & Stavovi o društvenim mrežama (skala2) & 150 & 0,975 & 0,298 & $\mathrm{da}$ \\
\hline 3. & Kvaliteta života (skala3) & 150 & 1,149 & 0,143 & $\mathrm{da}$ \\
\hline
\end{tabular}

Tablica 8. Rezultati deskriptivne statističke analize triju omjernih varijabli ( $N=150)$

\begin{tabular}{|l|l|c|c|c|}
\hline $\begin{array}{c}\text { Red } \\
\text { br. }\end{array}$ & \multicolumn{1}{|c|}{ Deskriptivni pokazatelj } & $\begin{array}{c}\text { Skala 1 } \\
\text { (slobodno } \\
\text { vrijeme) }\end{array}$ & $\begin{array}{c}\text { Skala 2 } \\
\text { (društvene } \\
\text { mreže) }\end{array}$ & $\begin{array}{c}\text { Skala 3 } \\
\text { (kvaliteta } \\
\text { života) }\end{array}$ \\
\hline 1. & Aritmetička sredina & 3,99 & 2,93 & 4,01 \\
\hline 2. & Medijan & 4,00 & 2,94 & 4,03 \\
\hline 3. & Najmanja vrijednost & 2,81 & 1,39 & 1,74 \\
\hline 4. & Najveća vrijednost & 4,95 & 4,50 & 5,00 \\
\hline 5. & Standardna devijacija & 0,483 & 0,455 & 0,716 \\
\hline 6. & Koeficijent varijacije & $12 \%$ & $16 \%$ & $18 \%$ \\
\hline
\end{tabular}

Pomoću t-testa utvrđene su razlike u slaganju s tvrdnjama o aktivnostima u slobodnom vremenu, stavovima o društvenim mrežama i kvaliteti života s obzirom na spol. Razlike u slaganju s tvrdnjama o aktivnostima u slobodnom vremenu, stavovima o društvenim mrežama te kvaliteti života s obzirom na završni opći uspjeh u prethodnom razredu i na dob provjerene su analizom varijance (F-testom). Rezultati su pokazali (Tablica 9) da između muških i ženskih ispitanika ne postoji statistički značajna razlika u pogledu aktivnosti u slobodnom vremenu $(p=0,928)$ niti u pogledu njihovih stavova o društvenim mrežama $(p=0,577)$. Međutim postoji statistički značajna razlika u pogledu njihove procjene kvalitete života $(p=0,001)$. Muški ispitanici dali su statistički značajno bolju procjenu kvalitete svog života u odnosu na ispitanice $(4,24$ $>3,87)$.

Između anketiranih ispitanika različitog općeg uspjeha u prethodnom razredu ne postoji statistički značajna razlika u pogledu aktivnosti u slobodnom vremenu $(p=0,522)$, stavova o društvenim mrežama ( $p=0,890)$ niti u pogledu procjene kvalitete njihova života $(p=0,857)$.

Ne postoji ni statistički značajna razlika u aktivnostima u slobodnom vremenu ( $p=$ $0,786)$, stavovima o društvenim mrežama $(p=0,354)$ i samoprocjeni kvalitete života $(p=0,158)$ s obzirom na dob učenika. 
Tablica 9. Rezultati t-testova i F-testova usporedbe aritmetičkih sredina ${ }^{4}$

\begin{tabular}{|c|c|c|c|c|c|c|c|}
\hline $\begin{array}{l}\text { Red. } \\
\text { br. }\end{array}$ & Varijabla & $\begin{array}{l}\text { Grupa } \\
\text { ispitan. }\end{array}$ & $\begin{array}{l}\text { Br. } \\
\text { uč. }\end{array}$ & $\begin{array}{l}\text { Aritm. } \\
\text { sredina }\end{array}$ & $\begin{array}{l}\text { Stand. } \\
\text { devij. }\end{array}$ & t ili F & $\mathbf{p}$ \\
\hline \multirow[t]{2}{*}{1.} & \multirow{2}{*}{$\begin{array}{l}\text { Aktivnosti u slobodno vrijeme } \\
\text { (skala } 1 \text { ) }\end{array}$} & muški & 58 & 3,95 & 0,428 & & \\
\hline & & ženski & 92 & 3,95 & 0,428 & $t=0,091$ & 0,928 \\
\hline \multirow[t]{2}{*}{2.} & \multirow{2}{*}{$\begin{array}{l}\text { Stavovi o društvenim mrežama } \\
\text { (skala 2) }\end{array}$} & muški & 58 & 2,96 & 0,573 & & \\
\hline & & ženski & 92 & 2,91 & 0,363 & $t=0,559$ & 0,577 \\
\hline \multirow[t]{2}{*}{3.} & \multirow[t]{2}{*}{ Kvaliteta života (skala 3) } & muški & 58 & 4,24 & 0,700 & & \\
\hline & & ženski & 92 & 3,87 & 0,690 & $t=3,244$ & $0,001 * * *$ \\
\hline \multirow[t]{4}{*}{4.} & \multirow{4}{*}{$\begin{array}{l}\text { Aktivnosti u slobodno vrijeme } \\
\text { (skala 1) }\end{array}$} & ocjena 2 & 3 & 3,89 & 0,500 & & \\
\hline & & ocjena 3 & 42 & 3,97 & 0,463 & & \\
\hline & & ocjena 4 & 66 & 3,90 & 0,414 & & \\
\hline & & ocjena 5 & 38 & 4,03 & 0,405 & $F=0,754$ & 0,522 \\
\hline \multirow[t]{4}{*}{5.} & \multirow{4}{*}{$\begin{array}{l}\text { Stavovi o društvenim mrežama } \\
\text { (skala 2) }\end{array}$} & ocjena 2 & 3 & 2,89 & 0,419 & & \\
\hline & & ocjena 3 & 42 & 2,97 & 0,488 & & \\
\hline & & ocjena 4 & 66 & 2,92 & 0,400 & & \\
\hline & & ocjena 5 & 38 & 2,90 & 0,524 & $F=0,210$ & 0,890 \\
\hline \multirow[t]{4}{*}{6.} & \multirow[t]{4}{*}{ Kvaliteta života (skala 3) } & ocjena 2 & 3 & 3,96 & 0,806 & & \\
\hline & & ocjena 3 & 42 & 3,93 & 0,828 & & \\
\hline & & ocjena 4 & 66 & 4,04 & 0,652 & & \\
\hline & & ocjena 5 & 38 & 4,07 & 0,712 & $F=0,256$ & 0,857 \\
\hline \multirow[t]{4}{*}{7.} & \multirow{4}{*}{$\begin{array}{l}\text { Aktivnosti u slobodno vrijeme } \\
\text { (skala 1) }\end{array}$} & 15 god. & 51 & 3,97 & 0,402 & & \\
\hline & & 16 god. & 26 & 3,94 & 0,399 & & \\
\hline & & 17 god. & 51 & 3,98 & 0,423 & & \\
\hline & & 18 god. & 18 & 3,87 & 0,509 & $F=0,354$ & 0,786 \\
\hline \multirow[t]{4}{*}{8.} & \multirow{4}{*}{$\begin{array}{l}\text { Stavovi o društvenim mrežama } \\
\text { (skala 2) }\end{array}$} & 15 god. & 51 & 2,86 & 0,417 & & \\
\hline & & 16 god. & 26 & 2,93 & 0,544 & & \\
\hline & & 17 god. & 51 & 2,94 & 0,444 & & \\
\hline & & 18 god. & 18 & 3,08 & 0,458 & $F=1,093$ & 0,354 \\
\hline \multirow[t]{4}{*}{9.} & \multirow[t]{4}{*}{ Kvaliteta života (skala 3) } & 15 god. & 51 & 4,18 & 0,729 & & \\
\hline & & 16 god. & 26 & 4,10 & 0,652 & & \\
\hline & & 17 god. & 51 & 3,91 & 0,718 & & \\
\hline & & 18 god. & 18 & 3,84 & 0,645 & $F=1,758$ & 0,158 \\
\hline
\end{tabular}

Tablica 10. Rezultati t-testa usporedbe aritmetičkih sredina

\begin{tabular}{|c|l|l|l|l|l|l|l|}
\hline $\begin{array}{c}\text { Red. } \\
\text { br. }\end{array}$ & \multicolumn{1}{|c|}{ Varijabla } & $\begin{array}{c}\text { Grupa } \\
\text { ispitanika }\end{array}$ & $\begin{array}{c}\mathbf{N}_{\mathbf{1}} \\
\mathbf{N}_{\mathbf{2}}\end{array}$ & $\begin{array}{c}\text { Aritm. } \\
\text { sredina }\end{array}$ & $\begin{array}{c}\text { Stand. } \\
\text { devij. }\end{array}$ & $\mathbf{t}$ & $\mathbf{p}$ \\
\hline 1. & Kvaliteta života & selo & 65 & 4,09 & 0,654 & & \\
& & grad & 85 & 3,95 & 0,758 & 1,172 & 0,243 \\
\hline
\end{tabular}

Rezultat t-testa (Tablica 10) pokazuje da ne postoji statistički značajna razlika u samoprocjeni kvalitete života srednjoškolaca $s$ prebivalištem u gradu u odnosu na one s prebivalištem na selu $(p=0,243)$.

Korelacijska analiza među varijablama: Broj korištenih društvenih mreža, Broj sati dnevnog korištenja društvenim mrežama i Prosječni dnevni broj sati slobodnog vremena i Samo-

4 Iz analize pod 4, 5 i 6 isključen je jedan učenik sa ocjenom 1.

Iz analize pod 7, 8 i 9 isključen je jedan učenik sa 14 godina i tri učenika sa 19 godina. 
procjene kvalitete života učenika (Tablica 11) pokazuje da je za sva tri para varijabli korelacija slaba i nije statistički značajna ( $p>0,05$ ). Nije ustanovljena veza između navedenih varijabli $i$ samoprocjene kvalitete života učenika.

Tablica 11. Rezultati korelacijske analize

\begin{tabular}{|c|l|c|c|c|}
\hline $\begin{array}{c}\text { Red. } \\
\text { br. }\end{array}$ & \multicolumn{1}{|c|}{ Varijable } & N & $\begin{array}{c}\text { Spearmanov } \\
\text { koeficijent } \\
\text { korelacije } \mathbf{( r}_{\mathbf{s}} \text { ) }\end{array}$ & p \\
\hline 1. & $\begin{array}{l}\text { Broj korištenih društvenih mreža } \\
\text { Kvaliteta života (skala3) }\end{array}$ & 147 & 0,06 & 0,456 \\
\hline 2. & $\begin{array}{l}\text { Broj sati dnevnog korištenja društv.mreža } \\
\text { Kvaliteta života (skala3) }\end{array}$ & 147 & $-0,05$ & 0,532 \\
\hline 3. & $\begin{array}{l}\text { Prosj.dnevni broj sati slobodnog vremena } \\
\text { Kvaliteta života (skala3) }\end{array}$ & 150 & 0,05 & 0,515 \\
\hline
\end{tabular}

Jednofaktorskom analizom varijance utvrđeno je da učenici/učenice različitih školskih smjerovrazličito procjenjuju kvalitetu svog života $(p=0,035)$.

Tablica 12. Rezultati F-testova usporedbe aritmetičkih sredina $(N=147)^{5}$

\begin{tabular}{|c|l|l|r|r|r|l|l|}
\hline $\begin{array}{c}\mathbf{R} \\
\mathbf{b}\end{array}$ & \multicolumn{1}{|c|}{ Varijabla } & \multicolumn{1}{|c|}{ Škola } & $\begin{array}{c}\text { Broj } \\
\text { učen. }\end{array}$ & $\begin{array}{c}\text { Aritm. } \\
\text { sredina }\end{array}$ & $\begin{array}{c}\text { Stand. } \\
\text { devij. }\end{array}$ & \multicolumn{1}{|c|}{$\mathbf{F}$} & p \\
\hline 1. & Kvaliteta života & gimnazija & 38 & 3,99 & 0,727 & & \\
\hline & & hotelijersko-turistička & 22 & 4,36 & 0,542 & & \\
\hline & & ekonomska & 15 & 3,74 & 0,748 & & \\
\hline & & prodavač & 21 & 4,20 & 0,600 & & \\
\hline & & kuhar, konobar, slastičar & 17 & 4,04 & 0,759 & & \\
\hline & & škola za modu i dizajn & 34 & 3,80 & 0,758 & 2,468 & $\mathbf{0 , 0 3 5 *}$ \\
\hline
\end{tabular}

Najnižu samoprocjenu kvalitete života imaju ispitanici ekonomskog i modno-dizajnerskog smjera, dok najvišu kvalitetu života procjenjuju učenici hotelijersko-turističkog smjera te smjera prodavač. Pomoću LSD (Least Significant Difference) post hoc testa utvrđeno je da postoji statistički značajna razlika u procjeni kvalitete života između ispitanika hotelijersko-turističke i ekonomske škole $(p=0,009)$, između polaznika hotelijersko-turističke škole i škole za modu i dizajn $(p=0,004)$ te između polaznika škole za prodavače i škole za modu i dizajn ( $p=$ $0,044)$.

Kako su se u dosadašnjim analizama kvalitete života spol i vrsta škole pokazale relevantnim varijablama, pomoću dvofaktorske analize provjeren je takav nalaz.

Tablica 13. Rezultati analize varijance (ANOVA) za kvalitetu života kao zavisnu kvantitativnu varijablu $(\mathrm{N}=147)^{6}$

\begin{tabular}{|l|c|c|c|c|c|}
\hline \multicolumn{1}{c|}{$\begin{array}{c}\text { Kvalitativna } \\
\text { varijabla }\end{array}$} & $\begin{array}{c}\text { Suma } \\
\text { kvadrata }\end{array}$ & df & $\begin{array}{c}\text { Sredine } \\
\text { kvadrata }\end{array}$ & F & p \\
\hline spol & 4,312 & 1 & 4,312 & 9,429 & $\mathbf{0 , 0 0 3}$ \\
\hline vrsta škole & 4,854 & 5 & 0,971 & 2,123 & 0,066 \\
\hline spol * vrsta škole & 3,070 & 5 & 0,614 & 1,343 & 0,250 \\
\hline
\end{tabular}

5 Iz ove su analize isključena su tri učenika iz Centra za obrazovanje zbog premale frekvencije

${ }^{6}$ Iz ove su analize isključena tri učenika iz Centra za obrazovanje zbog premale frekvencije. 
Dobiveni rezultati upućuju na tri zaključka:

1) Postoji statistički značajan utjecaj spola na samoprocjenu kvalitete života (zanemarujući vrstu škole). Ispitanici muškog spola pokazuju veće zadovoljstvo kvalitetom života od ispitanica $(4,27>3,85)$ i ta je razlika statistički značajna $(p=0,003)$.

2) Ne postoji statistički značajan utjecaj vrste škole na samoprocjenu kvalitete života (zanemarujući spol). Ispitanici ekonomske škole najniže procjenjuju kvalitetu života, dok ispitanici hotelijersko-turističke škole najvišom procjenjuju kvalitetu života $(3,74<4,36)$, no te razlike nisu statistički značajne.

3) Ne postoji statistički značajna interakcija između spola, vrste škole i samoprocjene kvalitete života $(p=0,250)$.

Veći uzorak u istraživanju vjerojatno bi pokazao i statistički značajan utjecaj vrste škole na kvalitetu života ( $p$ vrijednost od 0,066 je vrlo blizu granične vrijednosti od 0,05 ).

U svrhu utvrđivanja ovisnosti samoprocjene kvalitete života o demografskim obilježjima ispitanika (dob i spol), aktivnostima u slobodno vrijeme i stavovima o društvenim mrežama, primijenjena je hijerarhijska regresijska analiza kako bi se uočio doprinos demografskih obilježja takvoj, eventualnoj, ovisnosti. U ovom modelu regresijske analize status i redoslijed uključivanja pojedinih varijabli te njihove aritmetičke sredine su sljedeće:

$\begin{array}{llr}\text { Zavisna varijabla } Y & \text { kvaliteta života } & 4,01 \\ \text { Nezavisna varijabla } X_{1} & \text { dob ispitanika } & 16,29 \\ \text { Nezavisna varijabla } X_{2} & \text { spol ispitanika } & 1,61 \\ \text { Nezavisna varijabla } X_{3} & \text { aktivnosti u slobodno vrijeme } & 3,95 \\ \text { Nezavisna varijabla } X_{4} & \text { stavovi o društvenim mrežama } & 2,93\end{array}$

ANOVA analizom dobiveni su rezultati $(F=14,810 ; p<0,001)$ koji pokazuju značajnost koeficijenta multiple korelacije. Između Kvalitete života kao zavisne varijable i četiriju (naprijed navedenih) nezavisnih varijabli $X_{1}, X_{2}, X_{3}$ i $X_{4}$ postoji osrednja, pozitivna i statistički značajna korelacija (koeficijent korelacije $(R)=0,539$ ). Koeficijent determinacije $\left(R^{2}\right)=0,290$ što znači da je vezom između promatrane zavisne varijable $Y$ i nezavisnih varijabli $X_{1}, X_{2}, X_{3}$ i $X_{4}$ objašnjeno $29,0 \%$ odstupanja pa je po tome model multiple regresije slabije reprezentativnosti. Korigirani koeficijent determinacije (Adjusted $R$ Square) je 0,270.

Tablica 14. Pregled rezultata hijerarhijske regresijske analize $(N=150)$

\begin{tabular}{|c|c|c|c|c|c|}
\hline \multirow{2}{*}{ Model i varijabla u modelu } & \multicolumn{2}{|c|}{$\begin{array}{c}\text { Nestandardizirani } \\
\text { koeficijenti }\end{array}$} & \multirow{2}{*}{$\begin{array}{l}\text { Standardizirani } \\
\text { koeficijent beta }\end{array}$} & \multirow{2}{*}{$\mathbf{t}$} & \multirow{2}{*}{$p^{7}$} \\
\hline & B & $\begin{array}{l}\text { stand. } \\
\text { greška }\end{array}$ & & & \\
\hline 1 konstanta & 6,361 & 0,808 & & 7,872 & $<0,001 * * *$ \\
\hline dob & $-0,115$ & 0,052 & $-0,183$ & $-2,220$ & $0,028^{*}$ \\
\hline spol & $-0,294$ & 0,121 & $-0,201$ & $-2,438$ & $0,016^{*}$ \\
\hline 2 konstanta & 2,832 & 0,921 & & 3,076 & $0,003 * *$ \\
\hline dob & $-0,097$ & 0,047 & $-0,154$ & $-2,064$ & $0,041 *$ \\
\hline spol & $-0,297$ & 0,108 & $-0,202$ & $-2,740$ & $0,007 * *$ \\
\hline Aktivnosti u slobodnom vremenu & 0,719 & 0,118 & 0,429 & 6,092 & $<0,001 * * *$ \\
\hline Stavovi o društvenim mrežama & 0,134 & 0,111 & 0,085 & 1,208 & 0,229 \\
\hline
\end{tabular}

\footnotetext{
7 * statistička značajnost do $5 \%, * *$ statistička značajnost do $1 \%, * * *$ statistička značajnost do $0,1 \%$
} 
S prve dvije nezavisne varijable objašnjeno je 9,7\%, dok je sa druge dvije nezavisne varijable on $19,3 \%$, što na kraju daje ukupni postotak objašnjene varijance u čitavom modelu od $29,0 \%$. Model je u cjelini statistički značajan kako je već naprijed navedeno.

Od četiri nezavisne varijable tri su statistički značajne $(p<0,05)$. Značajnom se pokazala dob kao nezavisna varijabla $X_{1}(p=0,041)$, spol kao nezavisna varijabla $X_{2}(p=0,007)$ te aktivnosti u slobodnom vremenu kao nezavisna varijabla $X_{3}(p<0,001)$. Samo se stav o društvenim mrežama kao nezavisna varijabla $X_{4}$ nije pokazao statistički značajnom varijablom $(p=0,229)$ pa je isključen iz jednadžbe multiple regresije. Stoga jednadžba multiple regresije glasi:

$$
\hat{Y}=2,832-0,097 X_{1}-0,297 X_{2}+0,719 X_{3}
$$

Najveći relativni utjecaj na samoprocjenu kvalitete života imaju aktivnosti u slobodnom vremenu (beta koeficijent 0,719 ), dok najmanji utjecaj imaju godine života (beta koeficijent 0,097).

\section{ZAKLUČAK}

Na temelju ovog istraživanja doznajemo da srednjoškolci imaju u prosjeku četiri sata slobodnog vremena dnevno i da imaju autonomiju u odabiru aktivnosti u slobodnom vremenu. Svoje slobodno vrijeme provode s osobama koje smatraju prijateljima i koje vole. $U$ to vrijeme osjećaju se dobro i ugodno, bez stresa. Smatraju da su dobri i uspješni u aktivnostima kojima se bave u slobodno vrijeme, da imaju priliku izraziti svoje mišljenje i da ih okolina uvažava te se uočava njihovo međusobno prijateljstvo i povezanost.

Pokazalo se da se u vrlo velikom postotku (96\%) koriste društvenim mrežama. Najviše korištena društvena mreža je Instagram, slijedi Facebook, Snapchat i ostale mreže. Ispitanici se najčešće koriste dvjema ili trima društvenim mrežama u prosjeku 2,3 sata dnevno. Postoji statistički značajna povezanost između spola i vremena korištenja društvenim mrežama dnevno. Ispitanici ženskog spola više vremena provode koristeći se društvenim mrežama od ispitanika muškog spola. Najčešća svrha korištenja društvenim mrežama jesu kontakti s prijateljima putem chata ili poruka i pregledavanje fotografija i videozapisa. Mladi u ovoj dobi smatraju da su društvene mreže korisne, da su važno sredstvo informiranja, da čine njihov život interesantnijim i maštovitijim, a društvo naprednijim. Većina se smatra kompetentnima za samostalno korištenje društvenim mrežama, one im ne izazivaju nelagodu, sigurni su u ono što rade pomoću njih, nisu im dosadne i nemaju nikakvih bojazni koristeći se njima.

Srednjoškolci izražavaju zadovoljstvo sobom, svojom radnom sposobnošću i međuljudskim odnosima. Smatraju da njihov život ima smisao, uživaju u životu, uglavnom imaju dobru mogućnost koncentracije i dovoljno životne energije. Dobro prihvaćaju svoj vanjski izgled. Smatraju se informiranima i imaju vremena za sebe i aktivnosti po vlastitim željama. Zadovoljni su životnim uvjetima, mobilnošću i zdravstvenom skrbi.

Demografska obilježja ispitanika i aktivnosti u slobodnom vremenu pokazali su se statistički značajnim prediktorima samoprocjene kvalitete života srednjoškolaca. Od ispitivanih varijabli u ovome istraživanju relativno najveći utjecaj na samoprocjenu kvalitete života imaju aktivnosti u slobodnom vremenu, što je u skladu s tvrdnjom da je način provođenja slobodnog vremena u izravnoj vezi s pokazateljima kvalitete života (Perasović i Bertoluci, 2008), a najmanji dob čiji je raspon u ovom istraživanju vrlo malen (14 - 19 god.). Stavovi učenika o društvenim mrežama nisu se pokazali statistički značajnima u samoprocjeni kvalitete života ispitanika. Također je utvrđeno da se učenici urbanih i ruralnih područja ne razlikuju u samoprocjeni kvalitete svog života. No uočava se da učenici različitih smjerova srednjih škola različito procjenjuju kvalitetu svog života, a postoji i statistički značajna razlika u pogledu procjene kvalitete života prema spolu. Ispitanici muškoga spola dali su značajno bolju procjenu kvalitete svog života u odnosu na djevojke $(4,24>3,87)$. 
Zbog veličine uzorka podatci dobiveni ovim istraživanjem ne mogu se generalizirati na opću populaciju, ali mogu biti korisne smjernice i poticaj za buduća istraživanja ovoga područja.

\section{LITERATURA}

Arbona (2018) [INFOGRAFIKA] Koliko je Instagram korisnika u Hrvatskoj? https://www.arbona.hr/ blog/drustveni-marketing/infografika-koliko-je-instagram-korisnika-u-hrvatskoj/722. Pristupljeno 8. svibnja 2018.

Badrić, M., Prskalo, I. i Matijević, M. (2014). Primary school pupils' free time activities, Croatian Journal of Education, 17 (2), 299-331.

Bouillet, D. (2006). Kvaliteta života mladih: odgovornost zajednice i/ili obitelji. U V. Ilišin (Ur.) Mladi između želja i mogućnosti: Položaj, problemi i potrebe mladih Zagrebačke županije (str. 27-92). Zagreb: Institut za društvena istraživanja.

Boyd, D. (2014). It's complicated: the social lives of networked teens. New Haven: Yale University Press.

Byrne, T., Nixon, E, Mayock, P. \& Whyte, J. (2006). Free-time and leisure needs of young people living in disadvantaged communities. Dublin: Combat Poverty Agency Working Paper Series.

Car, S. (2010). Online komunikacija i socijalni odnosi učenika. Pedagogijska istraživanja, 7(2), 281 290.

Car, S. (2013). Adolescencija 21. stoljeća: društvena uvjetovanost, temeljne karakteristike i pedagoški izazovi. Pedagogijska istraživanja, 10(2), 285-294.

Caldwell, L.L., Baldwin, C.K., Walls, T. \& Smith, E. (2004). Preliminary effects of a leisure education program to promote healthy use of free time among middle school adolescents. Journal of Leisure Research, 36(3), 310-335.

Deci, E. L., Connell, J. P., i Ryan, R. M. (1989). Self-determination in a work organization. Journal of Applied Psychology, $74,580-590$.

Diener, E. \& Lucas, R. E. (2000): Explaining differences in societal levels of happiness: relative standards, need fulfillment, culture, and evaluation theory. Journal of Happiness Studies, 1(1), 4178.

Escribano, C., Diaz-Morales, J.F., Delgado, P., Collado, Ma.J. (2012). Morningness/eveningness and school performance among Spanish adolescents:

Further evidence. Learning and Individual Differences, 22 (3), 409-413.

Godbey, G. (2003). The Harried Leisure Class. Staffan Linder. Journal of Leisure Research. 32 (3), 91 106. Arlington: Parks \& Recreation.

Hanžek, D, Holenko, J., Kojadin, J., Kolesarić, J. i Morić, D. (2013). Istraživanje potreba mladih - slobodno vrijeme mladih. U E. Bužinkić (Ur.) Znam, razmišljam, sudjelujem. 6. bilten studija i mladima i za mlade (str. 56-103). Zagreb: Mreža mladih Hrvatske.

Howe, N. i Strauss, W. (2000). Millennials rising: the next great generation. New York: Vintage Books.

Huang, Y-T. (2013). A study on the relationships between leisure activity involvement, well-being, the benefits of serious leisure activity, and sports volunteer self-actualization in the changhua national games. The Journal of Human Resource and Adult Learning, 9(1), 12-25.

Ilišin, V. (2000), Promjene u slobodnom vremenu mladih. Napredak, 141 (4), str. $419-429$.

Ilišin, V., Bouillet, D., Gvozdanović, A., Potočnik, D. (2013). Mladi u vremenu krize: Prvo istraživanje IDIZ-a i Zaklade Friedrich Ebert o mladima. Zagreb: Institut za društvena istraživanja u Zagrebu i Friedrich Ebert Stiftung.

Ilišin, V., Marinović-Bobinac, A. i Radin, F. (2001). Djeca i mediji. Zagreb: IDIS.

Ilišin, V. i Spajić Vrkaš, V. (2015) Potrebe, problemi i potencijali mladih u Hrvatskoj. (istraživački izvještaj)

Iso-Ahola, S. (1980). The social psychology of leisure and recreation. Dubuque, IA: Drown Company Publishers. 
Kovčo Vukadin, I. (2016). Zadovoljstvo životom: individualna i obiteljska perspektiva. Kriminologija $i$ socijalna integracija. 24 (1).

Larsen, J.T., McGraw, A.P. \& Cacioppo, J.T. (2001). Can people feel happy and sad at the same time? Journal of Personality and Social Psychology, 81(4), 684-696.

Leversen, I., Danielsen, A. G., Birkeland, M. S., \& Samdal, O. (2012). Basic psychological need satisfaction in leisure activities and adolescents' life satisfaction. Journal of Youth and Adolescence, 41(12), 1588-1599.

Perasović, B. i Bartoluci, S. (2008). Slobodno vrijeme i kvaliteta života mladih. U Andrijašević, M. (Ur.), Zbornik radova međunarodne znanstveno-stručne konferencije Kineziološka rekreacija i kvaliteta života (str. 15-24). Zagreb: Kineziološki fakultet.

Prensky, M. (2005). Listen to the natives. Learning in the digital age. Educational Leadership 63(4), 8-13.

Previšić, V. (2000). Slobodno vrijeme između pedagogijske teorije i prakse. Napredak , 4, 403-409.

Roberts, D. F., Foehr, U. G., Rideout, V. J. \& Brodie, M. (1999). Kids and media at the new millennium: a comprehensive national analysis of children's media use. Menlo Park, CA: A Kaiser Family Foundation Report. Dostupno na https://kaiserfamilyfoundation.files.wordpress.com/2013/01/ kids-media-the-new-millennium-report.pdf

Roberts, D. F., Foehr, U. G. \& Rideout, V. (2005). Generation M: media in the lives of 8-18-year-old. Kaiser Family Foundation Study. Dostupno na https://kaiserfamilyfoundation.files.wordpress. com/2013/01/generation-m-media-in-the-lives-of-8-18-year-olds-report.pdf.

Ryan, R. M. i Deci, E. L. (2000). Intrinsic and Extrinsic Motivations: Classic Definitions and New Directions. Contemporary Educational Psychology, 25, 54-67. Cambridge, Massachusetts: Academic Press.

Tapscott, D. (2008). Grown Up Digital: How the Net Generation Is Changing Your World. New York: McGraw-Hill.

Tsai, C.-C., Lin, S. S. J. \& Tsai, M.-J. (2001). Developing an internet attitude scale for high school students. Computers \& Education, 37, 41-51.

Wang, W-C. \& Kao, C-H. (2006). An exploration of the relationships between free time management and the quality of life of wageearners in Taiwan. World Leisure Journal, 48 (1),24-33.

Žitnik, E. i Maglica, T. (2002). Bol i nada - Priručnik za prevenciju suicida kod mladih. Split: Udruga Mi. Centar za prevenciju suicida.

\section{Relationship Between Leisure Time and Quality of Life of High School Students}

Abstract: Students' leisure time, and the use of social networks as one of its inherent elements, can play an important role in the quality of their life. The aim of the research is to look into the features and predictive role of free time as well as the usage of social networks in life quality of the high school students. Appropriate instruments were used to collect data - these include demographic data, as well as a Leisure-Time Activity Scale, Social Media Attitude Scale and a Quality of Life Scale. The research was conducted on a sample of students from different high schools $(\mathrm{N}=150)$ from both urban and rural areas of Zagreb and Zagreb county. The results indicate that the demographic features of the examinees and free time activities are statistically significant predictors of secondary-school students' quality of life. Social network opinions haven't shown any statistical significance in the examinee's self-assessment of their life quality. There is a statistical significance within the self-assessed life quality and the frequency of social network usage regarding the gender of the students.

The research has yielded descriptive characteristics of the definition of the high school students' quality of life and leisure time, and explained the predictive relationships among leisure time, social networks and individual features of students in the self-assessment of the quality of their lives.

Keywords: social networks, life quality, free time, high school students 


\section{Zusammenhang zwischen Freizeit und Lebensqualität von Schülern der Oberstufe}

Zusammenfassung: Freizeit, und die mit ihr zusammenhängende Nutzung sozialer Netzwerke, kann in der Lebensqualität von Schülern der Oberstufe eine bedeutende Rolle spielen. Ziel der Untersuchung war es, die Eigenschaften und prädiktive Rolle von Freizeit und Nutzung sozialer Netzwerke in der Selbsteinschätzung der Lebensqualität von Schülern der Oberstufe zu erfragen. Für die Datenerhebung wurde ein Fragebogen benutzt, der außer den demographischen Daten auch die Skalen Freizeitaktivitäten, Meinungen über soziale Medien und Lebensqualität enthält. Die Untersuchung wurde auf einer Stichprobe von Schülern ( $N=150)$ unterschiedlicher Schulrichtungen aus städtischen und ländlichen Gebieten von Zagreb und der Zagreber Gespanschaft durchgeführt. Die Ergebnisse zeigen, dass die demographischen Merkmale der Befragten und die Freizeitaktivitäten statistisch signifikante Prädiktoren der Selbsteinschätzung der Lebensqualität der befragten Schüler darstellen. Die Meinungen über soziale Medien stellten sich als nicht statistisch signifikant heraus. Es gibt einen statistisch signifikanten Unterschied zwischen der Selbsteinschätzung der Lebensqualität und der Frequenz der Nutzung sozialer Netzwerke in Bezug auf das Geschlecht der Schüler.

Die Untersuchung brachte deskriptive Merkmale der Bestimmung von Lebensqualität und Freizeit von Schülern der Oberstufe hervor und die prädiktiven Zusammenhänge von Freizeit, sozialen Netzwerken und individuellen Schülereigenschaften in der Selbsteinschätzung ihrer Lebensqualität wurden geklärt.

Schlüsselwörter: Soziale Netzwerke, Lebensqualität, Freizeit, Schüler der Oberstufe 